\title{
Jan NOWICKI
}

Uniwersytet Warszawski

jan.m.nowicki@gmail.com

\section{GOTYK POLSKI?}

\section{ARCHITEKTURA JAKO NARZĘDZIE BUDOWANIA GRANIC RZECZYWISTYCH I WYOBRAŻONYCH W II POŁOWIE XIX WIEKU}

ABSTRACT Polish Gothic? Establishing Real and Imaginary Boundaries through Architecture in the II Half of the XIX Century

Intensive development of national identities is a characteristic feature of the XIX century European science, culture and politics. In Poland this process was of great importance. Disintegration of the state and lack of its institutions resulted in even more determined attempts to define and divide what is "ours" from what is "foreign". One of the most important ways of constructing this boundary was through architecture - its history and theory. In the second half of the XIX century more and more authors started to give their answers to the emerging question: are there any exceptional, individual features of Polish architecture? In this context I would like to investigate the concept of "Vistulian-Baltic" style, which is interpreted by scholars as a first attempt to define Polish national style in architecture. Closer insight into XIX century narratives reveals how imaginary and real boundaries were established through architecture and its theory.

Key words: gothic revival, gothic reception, Vistulian-Baltic style, national style, XIX century architecture, historicism, national identity, boundaries, medieval history

Słowa kluczowe: neogotyk, recepcja gotyku, styl wiślano-bałtycki, styl narodowy, architektura XIX wieku, historyzm, tożsamość narodowa, granice, historia średniowiecza 


\section{WPROWADZENIE}

XIX wiek był czasem intensywnego kształtowania się tożsamości wielu narodów zamieszkujących współczesną Europę. W rozdzielonym rozbiorami społeczeństwie polskim proces ten nabrał wyjątkowego charakteru. Brak państwa oraz granic politycznych potęgował potrzebę samookreślenia, oddzielenia tego, co „swojskie”, od tego, co „obce”. W II połowie XIX w. problem opisania i skonceptualizowania sztuki, historii i kultury polskiej stał się jednym z głównych motorów napędzających rozwój rodzących się dyscyplin humanistyki, takich jak historia, archeologia, etnologia, historia sztuki.

W opisanym procesie wyjątkową rolę odegrała architektura i jej teoria. Żadna bowiem $\mathrm{z}$ innych form sztuki nie determinuje naszych działań i nie wpływa na nasze postrzeganie otaczającej rzeczywistości tak mocno jak ona. Codzienne doświadczenie składa się z ciągłego nawiązywania relacji z domami, osiedlami, mieszkaniami, gmachami publicznymi, ulicami, przejściami podziemnymi, przystankami autobusowymi, dworcami, kościołami itd. M.in. z tego powodu Hans-Georg Gadamer stwierdził, iż budowla nigdy nie jest przede wszystkim dzietem sztuki. Jej przeznaczenia, na mocy którego należy ona do kontekstu życia, nie da się od niej oddzielić bez pomniejszenia jej rzeczywistości ${ }^{1}$.

Nic więc dziwnego, że to właśnie architektura stała się w II połowie XIX w. jednym z głównych narzędzi wyznaczania owych granic między tym, co „swojskie”, a tym, co „obce”. Za jej pomocą starano się podkreślać „polskość” miast i wsi oficjalnie podległych władzy obcych państw. Osiągnięcie tego celu wymagało jednak zdefiniowania, czym w zasadzie wyróżnia się architektura w Polsce.

W niniejszym artykule chciałbym skupić się na zjawisku neogotyckiego stylu wiślano-bałtyckiego ${ }^{2}$, który stanowił pierwszą próbę odpowiedzi na tak postawione pytanie. Próba jego zdefiniowania jest polem do postawienia zasadniczych pytań

H.-G. Gadamer, Prawda i metoda. Zarys hermeneutyki filozoficznej, przeł. B. Baran, Warszawa 2004, s. 229.

2 O stylu wiślano-bałtyckim najwięcej pisano w publikacjach: A. Majdowski, Nurt narodowy $w$ architekturze sakralnej Królestwa Polskiego od drugiej potowy XIX wieku, „Nasza Przeszłość: studia z dziejów Kościoła i kultury katolickiej w Polsce" 1965, t. 64, s. 5-54; tenże, Opoglądach na styl wiślano-battycki wpolskiejarchitekturze sakralnejXIX wieku, tamże 1992, t.78, s. 303-327; tenże, Studia zhistorii architektury sakralnej w Królestwie Polskim, Warszawa 1993; A.K. Olszewski, Przeglad koncepcji stylu narodowego w teorii architektury polskiej przetomu XIX i XX w., „Sztuka i Krytyka” 1956, t. 7, nr 3-4, s. 275-372, 391-394; K. Stefański, Polska architektura sakralna w poszukiwaniu stylu narodowego, Łódź 2002. Istotnym kontekstem są tu również prace dotyczące kategorii historyzmu w architekturze: W. Bałus, Zjawisko historyzmu w architekturze wieku XIX. Próba opisu, „Dzieła i Interpretacje” 1995, nr 3, s. 69-80; Sztuka i historia. Materiaty sesji Stowarzyszenia Historyków Sztuki. Kraków, listopad 1988, red. M. Bielska-Łach, Warszawa 1992; Z. Tołłoczko, „Sen architekta” czyli o historii i historyzmie architektury XIX i XX wieku, Kraków 2015. Warto również wspomnieć o zbiorowych publikacjach dotykających problematyki nacjonalizmu w sztuce: Art and Politics: The Proceedings of the Third Joint Conference of Polish and English Art Historians, ed. F. Ames-Lewis, P. Paszkiewicz, Warsaw 1999; Nacjonalizm w sztuce i historii sztuki 1789-1950, red. D.K. Konstantynow, R. Pasieczny, P. Paszkiewicz, Warszawa 1998. 
dotyczących wyobrażonych granic polskości, jak również sposobów kulturowego zawłaszczania krajobrazu, podkreślania jego przynależności do kultury polskiej³

Jakimi argumentami posługują się autorzy w celu uzasadnienia wyboru cech indywidualnych "polskiego" gotyku, gdzie i dlaczego przebiega według nich granica między tym, co „nasze”, a tym, co „obce”, jak rozumieją oni pojęcia takie jak „narodowy”, „rodzimy” czy „wiślano-bałtycki” - to główne pytania, na które szukam odpowiedzi w niniejszym artykule. Chciałbym tym samym przeciwstawić się traktowaniu wymienionych pojęć jako niewymagających tłumaczenia. Nie jest to jednak proste, ponieważ autorzy XIX-wieczni nie udzielają jasnych odpowiedzi na tak postawione pytania, lecz zazwyczaj posługują się określeniem „wiślano-bałtycki” bez podania dokładnej jego definicji. Z tego względu tak istotnym wydarzeniem dla recepcji gotyku w Polsce był konkurs na kościół św. Michała Archanioła i Floriana Męczennika w Warszawie z 1886 r. ${ }^{4}$ Dopiero w artykułach napisanych $\mathrm{w}$ odpowiedzi na warunki konkursu autorzy po raz pierwszy podjęli się sprecyzowania lub krytycznej oceny tego funkcjonującego już od dłuższego czasu pojęcia.

\section{GENEZA POJĘCIA „STYL WIŚLANO-BAŁTYCKI”}

W 1840 r. zakończono budowę nowej fasady katedry św. Jana Chrzciciela w Warszawie ${ }^{5}$. W kolejnych latach stała się ona obiektem ostrej krytyki. Stopniowo zaczęto dostrzegać, iż jej formy w nikłym stopniu przypominają zachowane (i stające się stopniowo przedmiotem badań) zabytki architektury średniowiecznej w Polsce. Z tego

3 W tym miejscu istotnym fundamentem wszelkich badań są najważniejsze prace dotyczące architektury neogotyckiej w Polsce, analizy twórczości kluczowych architektów oraz ich realizacji: W. Bałus, Architektura sakralna Teodora Talowskiego, „Zeszyty Naukowe Uniwersytetu Jagiellońskiego. Prace z Historii Sztuki” 1992, nr 20, s. 53-79; tenże, Dziatalność architektoniczna Jana Sasa-Zubrzyckiego w świetle jego poglądów teoretycznych, „Sprawozdania z Posiedzeń Komisji Naukowych Krakowskiego Oddziału PAN” 1990, t. 32, nr 2, s. 279-281; J. Frycz, Neogotyk i restauracja zabytków w Polsce, Warszawa 1973; T.S. Jaroszewski, Henryk Marconi i neogotyk, Białystok 1976; tenże, O siedzibach neogotyckich w Polsce, Warszawa 1981; A. Majdowski, Budownictwo kościelne w twórczości projektowej Józefa Piusa Dziekońskiego (1844-1927), Warszawa 1995; Z. Ostrowska-Kębłowska, Dzieje Kaplicy Królów Polskich czyli Ztotej w katedrze poznańskiej, Poznań 1997; J. Żywicki, Architektura neogotycka na Lubelszczyźnie, Lublin 1998; tenże, Urzędnicy: architekci, budowniczowie, inżynierowie cywilni... Ludzie architektury $i$ budownictwa $w$ województwie lubelskim oraz guberni lubelskiej $w$ Królestwie Polskim w latach 1815-1915, Lublin 2010.

4 Jedynym współczesnym artykułem poświęconym kościołowi św. Floriana jest: A. Majdowski, $Z$ dziejów budowy kościota pw. świętych Michata i Floriana, [w:] Świątynie prawego brzegu. Kościót katolicki $w$ dziejach prawobrzeżnej Warszawy, Warszawa 2009, s. 125-137. Autor skupia się w nim na faktografii związanej z przebiegiem konkursu oraz procesem budowy świątyni. Z kolei najistotniejsze źródła dotyczące obiektu to: Budowa kościota parafialnego na przedmieściu Praga, „Przegląd Techniczny" 1888, z. 25, nr 5, s. 115; J.P. Dziekoński, Kościót parafialny świętego Floryana na Pradze pod Warszawa, „Architekt” 1900, nr 1, s. 6-10; Konkurs na sporzaddzenie szkicu do projektu kościota dla parafii praskiej m. Warszawy, „Przegląd Techniczny” 1886, z. 23, nr 9, s. 263; Sprawozdanie komisji konkursowej z osądzenia szkiców projektu budowy kościota dla parafii praskiej m. Warszawy, „Przegląd Techniczny" 1887, z. 24, nr 4, s. 93.

5 Z. Tołłoczko, „Sen Architekta” czyli..., s. 89. 
powodu zarzucano autorowi owej przebudowy brak zainteresowania rodzimą sztuką czy też zbyt małą wiedzę na jej temat ${ }^{6}$. Począwszy od lat 70. XIX w., historycy i krytycy architektury coraz częściej koncentrują się na wyznaczaniu cech, które odróżniałyby gotyk „polski” od „angielskiego”, „francuskiego” czy „niemieckiego”.

Brak odpowiedniego terminu, którym można by opisać architekturę średniowieczną w Polsce, budził na tym etapie słuszny niepokój wśród historyków, konserwatorów i architektów. Istotą XIX-wiecznej teorii sztuki była bowiem kategoria stylu. Pojęcie to, mające swoją genezę w oświeceniowym encyklopedyzmie, służyło opisowi, katalogowaniu i etykietowaniu wszelkich zjawisk artystycznych ${ }^{7}$. W XIX w. nadawało ono architekturze tożsamość, bez której pozostawała ona poza zainteresowaniem twórców i znawców. Pojęcie stylu można tym samym interpretować jako XIX-wieczną strategię porządkowania informacji na temat sztuki i nadawania im określonej struktury.

Tymczasem jednak - jak zauważają polscy autorzy - ich rodzima architektura gotycka wciąż pozostaje bez własnej etykiety. Jest więc nieoswojona i niezrozumiała. Ponadto dopóki brakuje jednego opisującego ją terminu, nie ma ona dla ówczesnej krytyki statusu sztuki. Nie może być zatem przedmiotem teoretycznej refleksji. Potrzeba stworzenia terminu „styl wiślano-bałtycki” wynika tu zatem bezpośrednio ze struktury oświeceniowego myślenia o sztuce, zgodnie z którym zjawiska nienazwane nie istnieją. Jak pisze Wojciech Bałus, pojęcie stylu staje się tarcza, zastona, pozwalająca [...] spokojnie [...] spojrzećn na architektoniczne zjawisko i uczynićzeń cośznanego i oswojonego ${ }^{8}$. W omawianym piśmiennictwie ukucie terminu „,wiślano-bałtycki” wyprzedza zatem pogłębioną refleksję i przemyślaną odpowiedź na następujące pytania: czym właściwie ów styl jest? Jakiego typu formy architektoniczne obejmuje? Do jakiego obszaru geograficznego i okresu rozwoju gotyku się odnosi? Niemniej termin ten cieszy się popularnością.

Pojawia się jednak potrzeba pogłębionej refleksji nad funkcjonującym już pojęciem i wynika ona z przynajmniej dwóch przesłanek. Po pierwsze, pojawia się pytanie, czy zabytki z przypisaną etykietą "wiślano-bałtyckich” można uznać za sztukę „polską" Z problemem tym wiąże się również pytanie o to, które obiekty powinny być przedmiotem badań historyków architektury średniowiecznej w Polsce. Po drugie, mimo nieprecyzyjnego charakteru, termin ten zaczyna być powszechnie używany do opisu nowo wznoszonych budynków. Zwraca na tę kwestię uwagę Franciszek Ksawery Martynowski - dziennikarz, historyk i krytyk sztuki. Jak zauważa, stylu wiślano-bałtyckiego ogót publiczności nie zna prawie, a większość budowniczych [...] unikajaca studyow i samodzielnej twórczości, nie wie nawet gdzie szukać odpowiednich wzorów $[\ldots]^{9}$. Problem wskazany przez autora zasadza się na tym, iż nikt w zasadzie nie jest

W. Łuszczkiewicz, $O$ znaczeniu $w$ dzisiejszych czasach budownictwa średniowiecznego. Kilka uwag $z$ dziedziny sztuki, [w:] Ktosy i kwiaty, Kraków 1869, s. 202; K. Matuszewski, O architekturze u obcych i u nas uwagi ze stanowisk a estetycznego, „Biblioteka Warszawska” 1881, t. 3, s. 383.

W. Bałus, Gotyk bez Boga? W kregu znaczeń symbolicznych architektury sakralnej XIX wieku, Torun 2011, s. $129-132$.

8 Tamże, s. 132.

9 F.K. Martynowski, O stylu wiślano-battyckim, „Wiek: Gazeta Polityczna, Literacka i Społeczna” 1887, nr 51, s. 3 . 
w stanie zdefiniować, czym dokładnie jest styl wiślano-bałtycki - co w żaden sposób nie zniechęca ówczesnych publicystów i architektów do coraz częstszego posługiwania się tym terminem przy opisywaniu nowych, powstających właśnie obiektów. W ten sposób termin ten niejako samorzutnie zadomawia się w języku polskiej krytyki architektury.

Ujawnia się zarazem charakterystyczna dla analizowanego terminu niespójność. W zależności od kontekstu odnosi się on bowiem do realiów średniowiecznych bądź współczesnych autorom. Raz ma on określać historyczną tradycję architektury gotyku ceglanego o szerokim zasięgu (obejmującym obszar od Lubeki po Kurlandię i od Bałtyku do Karpat), innym zaś razem opisuje styl dopiero projektowany, klarujący się i wymagający czasu, który ma w przyszłości stać się środkiem wyrażania polskiej tożsamości narodowej poprzez architekturę. I choć ze współczesnej perspektywy jest to rażąca niekonsekwencja, dla XIX-wiecznych autorów oba te aspekty były tożsame.

Próby ogólnego choćby scharakteryzowania gotyku w Polsce i nadania mu tożsamości stoją zatem u podstaw wykształcenia się pojęcia „stylu wiślano-bałtyckiego”. Warto jednak podkreślić, iż pojawiły się także inne sformułowania, które z różnych względów nie zaistniały na większą skalę w piśmiennictwie, m.in. „styl piastowski”, „styl jagielloński” oraz „styl słowiańsko-bałtycki” ${ }^{10}$. Wielość propozycji zdaje się potwierdzać silną potrzebę odnalezienia terminu, przy pomocy którego można by ująć zjawisko gotyku w Polsce jako jedną całość. Pokazuje ona również, że proces ostatecznego wyklarowania się i popularyzacji formuły „stylu wiślano-bałtyckiego” jest stopniowy i niełatwy do uchwycenia.

Z uwagi na płynność znaczeniową samego pojęcia oraz stopniowość jego kształtowania się w czasie trudno o proste zestawienie poglądów pojawiających się w ówczesnej publicystyce. Tutaj właśnie znacząca jest rola konkursu na projekt kościoła św. Floriana w Warszawie. To kluczowy moment dla rozwoju refleksji nad stylem wiślano-bałtyckim, ponieważ narastające w prasie zainteresowanie formami gotyckimi znalazło w nim swój punkt kulminacyjny. Konkurs ten, ogłoszony w „Przeglądzie Technicznym” w 1886 r., jako pierwszy zawierał w warunkach wymóg zaprojektowania kościoła w stylu wiślano-bałtyckim. Warto w tym miejscu przytoczyć dokładne brzmienie zawierającego ów wymóg zapisu. Jak czytamy, styl budowy ma być ostro-tukowy ceglany, wodcieniu tak zwanym wiślano-battyckim ${ }^{11}$. Zwraca uwagę użyte w tym zdaniu sformułowanie „odcień tak zwany". Sprawia ono wrażenie, jak gdyby sami autorzy konkursu nie mieli pewności w precyzyjnym stosowaniu terminu „wiślano-bałtycki”. To przymiotnik „ostrołukowy" funkcjonuje tu jako niebudzące zastrzeżeń i jednoznaczne określenie stylu. W mojej opinii jest to jeden z przejawów wspomnianej niejasności: co właściwie owo pojęcie oznacza i czy uprawomocnione jest określanie nim osobnego stylu?

W tekstach powstających w związku z konkursem na kościół św. Floriana autorzy starają się rozstrzygnąć owe wątpliwości, próbują zdefiniować zakres przedmiotowy terminu bądź poddają go gruntownej krytyce. W tym kontekście kluczowe znaczenie

10 A. Majdowski, Studia z historii..., s. 42-45.

11 Konkurs na sporzadzenie..., s. 263. 
mają dwa artykuły opublikowane krótko po ogłoszeniu konkursu: $O$ stylu wiślano-battyckim Franciszka Ksawerego Martynowskiego ${ }^{12}$ oraz Kilka stów o naszem budownictwie w epoce ostrotukowej i jego cechach charakterystycznych Władysława Łuszczkiewicza ${ }^{13}$. Oba teksty dotyczą problemu cech dystynktywnych gotyku w Polsce, jednak ich autorzy reprezentują dwie przeciwstawne strategie w wyznaczaniu granicy między tym, co „nasze”, a tym, co „obce”. O ile Martynowski stara się terminem „styl wiślano-bałtycki” objąć możliwie jak największy obszar i opisać go jako podporządkowany „polskim” wpływom kulturowym, o tyle Łuszczkiewicz krytykuje takie podejście i skupia się na odrębności architektury krakowskiej. Z tego względu postawę pierwszego autora nazwałbym rozszerzającą. Polega ona na śmiałym włączaniu w zakres rozważań obiektów nieraz odległych (zarówno architektonicznie, jak i geograficznie) na podstawie dość ogólnych kryteriów. Analogicznie postawę drugiego z autorów określiłbym zatem jako zawężającą - ostrożniejszą, w której autor, wychodząc od pogłębionych badań zabytków najistotniejszych dla historii Polski i znajdujących się na obszarze o stosunkowo niedużym zasięgu (takich jak kościoły krakowskie), dopiero stopniowo rozszerza pole swoich zainteresowań o obiekty odleglejsze.

\section{POSTAWA ROZSZERZAJĄCA}

Przejdźmy do bardziej szczegółowego omówienia pierwszej postawy reprezentowanej przez Franciszka Ksawerego Martynowskiego. Już na wstępie artykułu autor stwierdza, iż główną przyczyną podjęcia tematu stylu wiślano-bałtyckiego jest troska o „zadowalający” wynik konkursu na kośció św. Floriana ${ }^{14}$. Troska ta jest jednak dość zastanawiająca. Pięć lat wcześniej bowiem, w pracy Na przetomie sztuki polskiej, ten sam autor pisał m.in., iż nie możemy się zgodzić na to aby tak zwany "gotyk wiślano-battycki" bytpolskim wytworem. Cata Meklemburgia i Pomorze stusznie upominaja się o ojcostwo jego ${ }^{15}$. Wówczas poszukujący polskiego stylu narodowego Martynowski postulował oparcie się na wzorach architektury drewnianej, ludowej, wpisanej w klasyczne ramy antycznej harmonii i proporcji ${ }^{16}$. Dlatego przy lekturze jego tekstów z różnych okresów automatycznie rodzą się pytania: czy istotnie stosunek autora względem gotyku tak radykalnie zmienił się w ciągu pięciu lat? Czy może odmienne stanowisko wynika z ogłoszenia konkursu na kościół „w odcieniu tak zwanym wiślano-bałtyckim”? Trudno tu o jednoznaczne odpowiedzi. Być może to realna szansa na wyznaczenie architekturze polskiej nowego kierunku - nawet takiego, który autor wcześniej krytykował - była dlań wystarczającym powodem, aby napisać artykuł sprzeczny z wcześniej

\footnotetext{
$12 \quad$ F.K. Martynowski, $O$ stylu..., s. 3.

13 W. Łuszczkiewicz, Kilka stów o naszem budownictwie w epoce ostrotukowej i jego cechach charakterystycznych, „Przegląd Techniczny” 1887, z. 24, s. 3-6, s. 53-54, 81-82, 115-117, 148-150.

$14 \quad$ F.K. Martynowski, $O$ stylu..., s. 3.

15 Tenże, Na przetomie sztuki polskiej, Warszawa 1882, s. 16.

16 K. Stefański, Polska architektura sakralna..., s. 32.
} 
głoszonymi tezami. Przykład ten zdaje się obrazować, że nieraz potrzeba posiadania nowego, własnego stylu narodowego wyprzedza głębszy namysł nad architekturą, a argumentacje poszczególnych autorów w zależności od okoliczności potrafią się w tej sferze znacznie różnić.

Martynowski jest zatem jednocześnie jednym z największych krytyków i piewców stylu wiślano-bałtyckiego. Wróćmy jednak do próby zakreślenia przez niego zakresu przedmiotowego pojęcia, z którym się zmaga. Jak pisze, obok tedy gotyku francuskiego, niemieckiego, angielskiego itp., wytworzyt się ostrotuk polski, różniacy się znacznie od tamtych [...]. Gotyk ten wtaśnie zwiemy „wiślano battyckiem”, który znowu w charakterze swoim różni się mocno od ostrotuku rozwiniętego w Krakowie [...] $]^{17}$. Prawdopodobnie pod wpływem ustaleń Łuszczkiewicza autor wyłącza architekturę krakowską z zakresu przedmiotowego stylu wiślano-bałtyckiego.

Należy w tym miejscu zadać pytanie, jak Martynowski określa pozostały obszar oraz w jaki sposób wiąże znajdującą się na nim architekturę z polską tożsamością narodową. Jak czytamy, według autora styl wiślano-bałtycki rozprzestrzenił się hen, poza Gdańsk oraz w Wirtenbergii, Branderburgsczyźnie i sasiednich krajach, a więc na ziemiach bądź pośrednio, bądź bezpośrednio podlegtych wptywom lub bertu Piastów i Jagiellonów ${ }^{18}$. Obszar, który w ogólny sposób stara się zarysować Martynowski, pokrywa się z tym, co współczesna literatura przedmiotu rozumie pod pojęciami „gotyk ceglany” lub „Backsteingotik”. Zarówno dla terminów używanych obecnie, jak i dla formuły „stylu wiślano-bałtyckiego", wyróżnikiem jest cegła jako główny materiał budowlany. Niemniej jednak tylko omawiany termin XIX-wieczny sugeruje przynależność tego rodzaju architektury ceglanej do tradycji polskiej - właśnie poprzez zastosowanie w samej już nazwie cząstki „wiślany”. To tereny położone wzdłuż Wisły, od jej źródła aż do Bałtyku, miałyby być kolebką tego rodzaju budownictwa. Termin ten wyznacza zatem obszar geograficzny, do którego ma być stosowany, prezentując jednocześnie wspomniane rozszerzające rozumienie ,polskiego" gotyku.

Uprawomocnienie spójności tak rozległych terenów i ich przynależności do kultury polskiej opiera się w tekście Martynowskiego na dwóch filarach. Po pierwsze, miałyby być one w mniejszym lub większym stopniu powiązane $\mathrm{z}$ „polskimi” dynastiami. Teza ta nie jest raczej podejmowana przez innych autorów, zapewne z uwagi na jej dużą dyskusyjność. Trudno byłoby również poddać ją głębszej analizie, gdyż sam Martynowski nie tłumaczy się z niej w żaden sposób.

Po drugie - na co, jak sądzę, warto zwrócić szczególną uwagę - odwołuje się on do tezy o słowiańskich korzeniach zamieszkującej te tereny ludności, która mimo późniejszej kolonizacji niemieckiej trwała przy swoich tradycjach. To z jej wrażliwości estetycznej, potrzeb i warunków lokalnych miałby wyrastać ten specyficzny odcień sztuki gotyckiej. Jak czytamy u Martynowskiego, okoliczność ta mówi dosadnie, że gotyk wiślano-battycki jest wytworem stowiańsko-polskim, wystawionym od czasu do czasu na silne wptywy Niemiec i krzyżactwa. Nie zapominajmy, że we wskazanych prowincyach,

$17 \quad$ F.K. Martynowski, $O$ stylu..., s. 3.

18 Tamże. 
dzisiaj niemieckich, w epoce rozwijania się owego stylu, duch i ludność stowiańsko-polska, jest podktadowym czynnikiem spotecznym ${ }^{19}$.

Teza ta ma swoje umocowanie w ówczesnym piśmiennictwie historycznym. W mojej opinii stwierdzenia tego rodzaju mają źródło w rodzącym się równolegle zainteresowaniu tradycją Słowian. Przykładem może być tu rozprawa historyka Stanisława Marońskiego Stowianie Meklemburscy i walka stronnictwa niemieckiego ze stowiańskiem przy wyborze biskupa dyecezji szweryńskiej opublikowana w $1881 \mathrm{r}^{20}$ Miejscami charakteryzuje się ona skrajną idealizacją idylli słowiańskiego społeczeństwa, które miałoby być brutalnie zdominowane i zniszczone przez barbarzyńskich Niemców. Przykładowo, autor pisze: Ośm wieków wstecz, a panowata w ziemi tej stowianska uczciwość i rzetelność; szczera, serdeczna gościnność i wesota towarzyskość; uczciwosś i tagodność obyczajów. [...] Zatracony jezyk, przenarodowieni, wypędzeni lub wytęieni mieszkańcy, a na ich ziemi, koścmi ich umierzwionej rozpanoszyt się żywiot germański i wzrasta dalej, jakoby dąb na cudzej a bujnej roli ${ }^{21}$.

Na potwierdzenie swoich tez o słowiańskiej przynależności kulturowej Meklemburgii, Pomorza Przedniego i Prus autor ten przeprowadza rozbudowane wywody etymologiczne nazw miejscowości, zgodnie z założeniem, iż prawda o ich słowiańsko-polskim charakterze ujawnia się poprzez język. $\mathrm{Z}$ tej postawy wynika również konsekwentne posługiwanie się nazwami polskimi (nazwy niemieckie - w domyśle przeinaczone podaje w nawiasach).

Wydaje się, że zarówno rozprawę Marońskiego, jak i artykuł Martynowskiego możemy rozpatrywać w kategoriach walk i sporów o charakterze politycznym pomiędzy narodami - rozgrywanych na polu rodzących się dyscyplin naukowych. Na marginesie warto zauważyć, iż kwestia średniowiecznej kolonizacji niemieckiej będzie antagonizowała autorów polskich i niemieckich przez większość XX w., eksploatowana także przez hitlerowską propagandę. Dopiero współczesne opracowania naukowe starają się w tej kwestii wyjść poza politykę i związane z nią spory ${ }^{22}$.

W dalszej części artykułu Martynowski definiuje cechy stylu wiślano-bałtyckiego oraz podaje katalog przykładów, na których mogą oprzeć się autorzy projektów kościoła praskiego. Za formy charakterystyczne autor uznaje częste artykułowanie ścian za pomocą kompozycji „nisz” (dziś powiedzielibyśmy: blend) i pilastrów, silne akcentowanie arkad profilowaniami oraz powszechność wielobocznych, prostych filarów, z których kapiteli wychodzą mocno zaznaczone żebrowania ${ }^{23}$. Zauważa on powszechność szczytów schodkowych, ale też rzadkość występowania „przeźroczy”, czyli maswerkowych, przestrzennych artykulacji fasad. Choć oczywiście nomenklatura naukowa uległa od czasów Martynowskiego licznym przekształceniom, wydaje się, iż podany przezeń

19 Tamże.

20 S. Maroński, Stowianie Meklemburscy i walka stronnictwa niemieckiego ze stowiańskiem przy wyborze biskupa dyecezji szweryńskiej, „Biblioteka Warszawska” 1881, t. 3. s. 22-48.

21 Tamże, s. 30.

22 Zob. F. Graus, Germans and Slavs, [w:] The Expansion of Central Europe in the Middle Age, red. Nora Berend, Farnham 2012, s. 149-176; J.M. Piskorski, The Medieval Colonization of Central Europe as a Problem of World History and Historiography, [w:] The Expansion..., s. 215-236.

23 F.K. Martynowski, O stylu..., s. 3. 
zestaw cech na poziomie ogólnym trafnie charakteryzuje najbardziej powszechne formy architektury analizowanego regionu.

Wybór przykładów dla stylu wiślano-bałtyckiego jest u Martynowskiego bardzo szeroki. Autor przywołuje budowle świeckie i sakralne, przynależne różnym regionom historycznym. Poznań, Włocławek, Pelplin, Frombork, Toruń, Wilno, Kowno, Lubeka, Wismar, Malbork, Bydgoszcz, Krzywino, Kobylin, Warszawa, Płock - to lista głównych miast, których budynki pojawiają się na liście Martynowskiego ${ }^{24}$. Autor dopatruje się stylu wiślano-bałtyckiego również w elementach kościołów franciszkańskiego i dominikańskiego w Krakowie i św. Jakuba w Sandomierzu, a także w szczycie ratusza wrocławskiego.

Tak skonceptualizowana i opatrzona przykładami charakterystyka stylu wiślano-bałtyckiego jest, w moim przekonaniu, efektem powtarzanych w piśmiennictwie już od wielu lat ogólnych sformułowań. Dla przykładu w 1881 r. Karol Matuszewski, krytykując fasadę katedry świętego Jana w Warszawie, pisze: wskazówek i motywów do planu odbudowania światyni w stylu ostrotukowym, mojem zdaniem, należato szukać w charakterystycznych zabytkach polskiego, czyli tak zwanego wiślano-battyckiego ostrotuku, jakiem i sa kościoty w Krakowie, Wiślicy, Wtoctawku i innych miastach ${ }^{25}$. Sformułowania tego typu zdają się pokazywać, iż u większości autorów określenie „styl wiślano-bałtycki” funkcjonuje jako samotłumaczące się wyrażenie, obrazowane za pomocą kilku ważnych, ale raczej arbitralnie zestawianych obiektów. Jeden z najpóźniejszych przykładów tego typu wypowiedzi znajdziemy w rozprawie Antoniego Brykczyńskiego z 1893 r. Jak czytamy, mając za watek wytacznie cegte, wyrodzit sie na odtam gotyku wiślano-battyckiego, bo nad brzegiem tego morza począwszy od Kurlandji i koto naszej gtównej rzeki, aż do Krakowa, przede wszystkim się rozwiną ${ }^{26}$. Stąd też, moim zdaniem, porządkujący wysiłek Martynowskiego, powiązany z przełomowym konkursem na kościół praski, zasługuje na odpowiednie wyeksponowanie.

Źródeł zmiany jego stosunku wobec stylu wiślano-bałtyckiego szukałbym z kolei w splocie wielu czynników. Wyklarowanie się i popularyzacja samego terminu, ambicja skierowania współczesnej autorowi architektury na nowe tory, a także próba wielopoziomowego udowodnienia samodzielności i rozległego wpływu sztuki polskiej w ramach rodzącej się historii architektury europejskiej były - jak sądzę - istotnymi elementami składającymi się na wnioski autora.

\section{POSTAWA ZAWĘ̇̇AJĄCA}

Stwierdzenia Martynowskiego nie są jednak oparte na pogłębionych badaniach. Porządkuje on jedynie i wzbogaca o przykłady poglądy pojawiające się w tym czasie w piśmiennictwie. Rozważania autora nie mają charakteru naukowego, gdyż nie posługuje się on

Tamże.

25 K. Matuszewski, $O$ architekturze u obcych..., s. 383.

26 A. Brykczyński, W jakim stylu najwtaściwiej u nas kościoty budować?, „Przegląd Katolicki” 1893, nr 46, s. 726. 
odpowiednimi narzędziami. Obiekty, które wymienia, nie są poddane analizie, nie korzysta on ze źródeł, czasem nie tłumaczy się z tez, które stawia.

Pionierem badań nad architekturą gotycką, który operuje już odpowiednim warsztatem, jest niewątpliwie Władysław Łuszczkiewicz, jak nikt inny zdający sobie sprawę z zapóźnienia polskiej nauki w tym zakresie. Pisze on: chcęprzyjś́c w pomoc tym, którzy pragna obeznać się ze znaczeniem dziet sztuki Krakowa, dowiedzieć się, co posiadamy prawdziwie ważnego pod tym względem, jak stoimy na tem polu dziejowym, które tak licznych ma dziś za granica pracowników ${ }^{27}$. Główną ambicją autora jest zatem rozpoznanie rodzimego materiału zabytkowego wraz z ustanowieniem pewnej wartościującej hierarchii. W związku z tym jego prace stanowią w przeważającej większości krótkie opracowania konkretnych obiektów, m.in. kościoła Bożego Ciała i kościoła św. Katarzyny z klasztorem ojców augustianów w Krakowie, Sukiennic, klasztorów w Mogile i Wąchocku ${ }^{28}$. Wobec ogromnego dorobku naukowego i dydaktycznego Łuszczkiewicza trudno wskazać autora, który w drugiej połowie XIX w. cieszyłby się większym autorytetem w dziedzinie rodzącej się historii architektury średniowiecznej w Polsce.

Oprócz tworzenia monografii konkretnych obiektów Łuszczkiewicz publikuje również teksty o charakterze publicystycznym, polemicznym oraz popularyzatorskim. Nie stroni w nich od zajmowania stanowiska w kwestiach współczesnej mu architektury. Jak pisze, jednak o przysztości szczéśliwszej wątpić dziś nie godzi się, bo jako przygotowanie do niej uważać trzeba wtaśnie to krzątanie się okoto poznania doktadnego historyi i rozwoju budownictwa $w$ przesztośc $i^{29}$. Łuszczkiewicz reprezentuje zatem postawę ostrożną $\mathrm{w}$ formułowaniu daleko idących wniosków i dopiero na gruncie pogłębionej analizy stara się ujmować dzieła architektoniczne w rozleglejszych kategoriach stylowych. Przede wszystkim z tego względu jest on jednym z głównych krytyków koncepcji stylu wiślano-bałtyckiego, w której, jak już zostało wspomniane, ukonstytuowanie się terminu wyprzedza refleksję nad jego zakresem przedmiotowym. Łuszczkiewicz zaś postępuje zupełnie odwrotnie punktem wyjścia dla jego szerszych rozważań są badania nad architekturą krakowską, która, w jego opinii, stanowi najważniejsze dziedzictwo średniowiecza.

Zanim przejdziemy do analizy zawartych w rozprawach Łuszczkiewicza stwierdzeń, należy postawić sobie pytanie, dlaczego to właśnie XIV-wieczna architektura Krakowa jest tą, na której Łuszczkiewicz buduję tezę o odrębności gotyku w Polsce. Dlaczego wydaje mu się ona wyborem intuicyjnym, niewymagającym wyjaśnień? Otóż trudno z historiografii polskiego średniowiecza wybrać dogodniejszy okres dla oparcia na nim narracji o wielkości narodu, państwa i sztuki. Wiek XIV jest czasem restauracji monarchii Piastów po okresie rozbicia dzielnicowego. Utożsamiany jest do dziś z okresem

27 W. Łuszczkiewicz, Pomniki architektury od XI do XVII wieku ze stanowiska historyi sztuki, t. 1, Kraków 1872 , s. 5.

28 Tenże, Kościót Bożego Ciata: jego dzieje i zabytki, Kraków 1898; tenże, Kościót św. Katarzyny z klasztorem OO. Augustyanów, Kraków 1898; tenże, Sukiennice krakowskie: dzieje gmachu i jego obecnej przebudowy, Kraków 1899; tenże, Wieś Mogita przy Krakowie, jej klasztor cysterski - kościótek farny i kopiec Wandy, Kraków 1899; tenże Reszty romańskiej architektury dawnego opactwa cysterskiego w Wąchocku, Kraków 1892.

29 W. Łuszczkiewicz, O znaczeniu w dzisiejszych czasach..., s. 200-201. 
intensywnego rozwoju państwa w wielu dziedzinach. Na ten wiek przypada panowanie Kazimierza, będącego jedynym królem o przydomku „Wielki”, który był ostatnim przedstawicielem Piastów na polskim tronie. Piastowie zaś, co wydaje mi się warte podkreślenia, to dynastia wyrosła z zamierzchłej, jeszcze pogańskiej przeszłości państwa. Trudno zatem o dogodniejszy okres stanowiący w wyobraźni XIX-wiecznej moment unaoczniania się tożsamości narodu w sztuce. Sam Kraków, od XIV w. pełniący funkcję stolicy skonsolidowanego państwa, jest materialnym dowodem jego siły objawiającej się w rozwoju architektury. $Z$ drugiej strony nie można też pominąć faktu, iż to właśnie z Krakowem Łuszczkiewicz był najbardziej związany.

Przyjrzyjmy się zatem głównym tezom Łuszczkiewicza, z których wynika jego późniejsza krytyka narzucenia wymogu posiadania „odcienia tak zwanego wiślano-bałtyckiego” projektom kościoła praskiego. Punktem wyjścia rozważań badacza jest sposób, w jaki rozumie on rozwój architektury średniowiecznej. Jak pisze, pomijajac więc ozdoby [...] gtównym bodżcem do ksztatcenia się budownictwa w wiekach średnich, jest walka z materyatem, która nakazuje szukać ciagle i ciagle coraz doskonalszych środków, do coraz śmielszych budowl. I to jest cata bistorya średniowiecznego budownictwa kościelnego ${ }^{30}$. To wielowiekowa, konstrukcyjna walka średniowiecznych budowniczych z prawami fizyki jest dla autora głównym motorem rozwoju architektury. Badacz krytykuje więc architektów, którzy jedynie poprzez plany lub ornamenty naśladują wzory gotyckie. Zauważa: Czyż godzi się tworzyć teraz systemata, charakteryzujace epoki z rozktadu planu kościelnego albo z jego ornamentyki, lub twierdzić, żeśmy naśladowali krzyżackie budowy ceglane czysto. Daleko więc jest rozsądniej wejśc na drogę konstrukcyjna co do badania zabytków, bo raz jak powiedzieliśmy leżato to w gtównej dążności architektów średniowiecznych ${ }^{31}$. Fragment ten pokazuje, że podstawową tezą badań Łuszczkiewicza jest pierwszorzędna rola rozwiązań konstrukcyjnych względem wszelkich innych aspektów gotyckiego budownictwa.

Autor wychodzi z założenia, iż wraz z rozwojem form gotyckich budowniczowie w różnych regionach Europy mierzyli się z podobnymi problemami. W tym kontekście opisuje on jeden $\mathrm{z}$ kluczowych dylematów konstrukcji gotyckiej - w jaki sposób zrównoważyć siły działające na ściany nawy głównej w systemie bazylikowym. Siła ciążenia działa w kierunku wertykalnym i jest w naturalny sposób przejmowana przez filary międzynawowe. Siła rozporu działa z kolei horyzontalnie i wynika z parcia sklepień i dachu na ściany nawy głównej, które w przypadku nieodpowiedniej konstrukcji rozchylają się na boki, grożąc zawaleniem całej budowli.

Najpowszechniejszym rozwiązaniem, stosowanym m.in. w katedrach francuskich, są zewnętrzne łuki oporowe, które przenoszą siłę rozporu ponad dachami naw bocznych na rozbudowane przypory. Architektura gotycka w Polsce rzadko jednak posługuje się tym elementem konstrukcyjnym. Jak pisze Łuszczkiewicz, $w$ tym razie trzeba byto [...] uciec się [...] do wprowadzenia szkarp w środek kościota po za kolumny, jak do tego przyszli jedynie na świecie, budowniczowie krakowskich kościotów [...] $]^{32}$. Mistrzowie

\footnotetext{
30 Tamże, s. 202-203.

31 Tamże, s. 207.

32 Tamże, s. 206.
} 
odpowiedzialni za budowę krakowskich bazylik zamiast przerzucać łuki oporowe nad dachami naw bocznych, postanowili wzmocnić konstrukcję poprzez dostawienie uskokowych przypór do zewnętrznych ścian nawy głównej, które schodzą wzdłuż niej do samej posadzki, wnikając w przestrzeń naw bocznych.

Spostrzeżenia Łuszczkiewicza w kwestii odrębności „szkoły krakowskiej” powinny mieć według niego istotne przełożenie także na współczesną mu architekturę. Jak pisze, idąc krok w krok za kształceniem konstrukcyi, zyskujemy nie tylko wiedzę o wtasnościach naszej w budownictwie szkoty, ale zyskujemy praktyke, czy to w wyborze materyatu, czy w przedsięwzietych restauracyjach, czy nakoniec przy nowo stawiać się mających gmachach $[. . .]^{33}$. Opisywane jednak przez Łuszczkiewicza rozwiązanie konstrukcyjne jest przez współczesnych mu architektów krytykowane, głównie ze względu na niepraktyczność, nieforemność filarów międzynawowych i utratę dostępnej powierzchni wewnątrz kościoła ${ }^{34}$.

Łuszczkiewiczowi nie idzie jednak o praktyczność rozwiązania, jego doskonałość konstrukcyjną, efektowność czy walory estetyczne. Prawdziwie istotne dla badacza jest stwierdzenie, iż „budowniczowie krakowscy”, mierząc się z tym samym problemem konstrukcyjnym, co mistrzowie zachodnioeuropejscy, doszli do swoich indywidualnych rozwiązań. Pisze on: Powiedzieliśmy wyżej, że dowiodtszy jako architektura ksztatcita się u nas na miejscu co do konstrukcyi, dowodzimy, żémy posiadali wtasnych budowniczych ${ }^{35}$. „System krakowski" jest dla Euszczkiewicza dowodem na samodzielność architektury gotyckiej w Polsce. Indywidualność tego właśnie rozwiązania ma dla niego fundamentalne znaczenie, ponieważ jest ono związane z ewolucją konstrukcji, którą, jak już wspomniano, badacz uważa za esencję stylu gotyckiego i jego najważniejsze osiągnięcie.

Należy w tym miejscu podkreślić, iż już autorzy z epoki zwrócili uwagę na najsłabszy punkt tak sformułowanej tezy. Mianowicie cytowany już wielokrotnie Martynowski zauważa, że wpuszczenie przypór nawy głównej do wnętrza kościoła jest rozwiązaniem obecnym również w kościołach węgierskich i niemieckich ${ }^{36}$. Nie umniejsza to oczywiście osiągnięć Łuszczkiewicza, należy jednak dostrzec pewne pozanaukowe ambicje towarzyszące tworzeniu konstruktów takich jak omówiona „szkoła krakowska”. Potrzeba posiadania cechy wyjątkowej na tle architektury europejskiej skutkowała często przymykaniem oka na występowanie podobnych motywów w innych regionach Europy.

Zapoznawszy się z główną tezą Łuszczkiewicza, która stoi u podstaw wyodrębnienia przezeń architektury krakowskiej na tle innych dzieł architektury gotyckiej w Polsce, przejdźmy do tekstu fundamentalnego dla poniższej analizy. Rok po ogłoszeniu konkursu na kościól św. Floriana w Warszawie Łuszczkiewicz publikuje w „Przeglądzie Technicznym" swoją wieloczęściową rozprawę, zatytułowaną Kilka stów o naszem budownictwie $w$ epoce ostrotukowej i jego cechach charakterystycznych. Głównym celem autora jest krytyka „stylu wiślano-bałtyckiego”, czemu daje wyraz na samym początku wywodu. Pisze: Powiedzmy otwarcie, mamy na myśli btąd wiążacy gotyckie budowle kościelne i świeckie

Tamże, s, 208.

34 J.P. Dziekoński, Kościót parafialny świętego..., s. 8.

35 W. Łuszczkiewicz, O znaczeniu w dzisiejszych czasach..., s. 207.

36 A. Majdowski, Studia z historii..., s. 54. 
Pomorza, Prus Ksiażęcych, Brandenburgii, Warmii itp. z zabytkami XIV wieku Krakowa, Gniezna, Sandomierza, Niepotomic, Biecza, Krosna, Olkusza, Skalbmierza, nawet Lwowa itp., boć przecie, tak dawniej zwany styl, dziś na szczęście tylko odcień stylowy jak go mieniq wiślano-battycki ma być charakterystycznym dla budowli gotyckich catego kraju ${ }^{37}$. Nie ma wątpliwości, iż tekst ten powstaje niejako w odpowiedzi na wymóg dotyczący konkursu na kościół św. Floriana. Po pierwsze, Łuszczkiewicz publikuje go w „Przeglądzie Technicznym” - piśmie, z którym nie był wcześniej w żaden sposób związany, a w którym informacja o wspomnianym konkursie została opublikowana. Po drugie, powstaje on niedługo po jego ogłoszeniu. Po trzecie, sugeruje to zawarta w cytowanym fragmencie uwaga Łuszczkiewicza dotycząca traktowania stylu wiślano-bałtyckiego jedynie jako „odcienia stylowego". Podobne sformułowanie znajdujemy w cytowanej już treści warunków konkursu ${ }^{38}$.

Jednakże celem rozprawy nie jest wyłącznie negatywna ocena zbyt uogólniającego i ujednolicającego postrzegania całości architektury gotyckiej w Polsce i przypisania właściwości różnych jej odmian jednemu stylowi. W końcu duża część autorów, jak na przykład przywoływany Martynowski, zwraca wówczas uwagę na odrębność architektury krakowskiej. Stoję na stanowisku, że dużo istotniejszym celem tej rozprawy jest krytyka gotyckiej architektury ceglanej północnych ziem polskich oraz udowodnienie wyższości artystycznej architektury krakowskiej XIV w. i jej silniejszego związku z kulturą polską. Rozpatrywana pod tym kątem rozprawa Łuszczkiewicza wymaga pogłębionej analizy. Chciałbym w związku z tym omówić główne argumenty, jakie autor stosuje w celu dyskredytacji uważanych za obce wzorów.

Pierwszy z nich związany jest z brakiem dostatecznej wiedzy na temat genezy architektury tamtejszych obiektów. Łuszczkiewicz wskazuje, iż gotyk ceglany północno-wschodnich tzw. nizin niemieckich jest tak gruntownie opisany przez zagranicznych autorów, że posługują się nim sprawnie nawet prowincjonalni architekci. Pochodzenie tego typu budownictwa jest jednak wciąż dla badacza niepewne. Najprawdopodobniej jednak jest ono „germańskie” - dla porównania Łuszczkiewicz wskazuje romańskie klasztory w Jerichow i Lehnin. Ponadto rozważa również zabytki Danii oraz Skandynawii ${ }^{39}$. Tak rozumiany styl nie może być zatem dobrym wzorem dla architektury wyrażającej charakter narodu polskiego i jego kultury.

W tym kontekście Łuszczkiewicz ponownie zarzuca nieokreślonym autorom koncepcji stylu wiślano-bałtyckiego łączenie architektury „nizin niemieckich” i krakowskiej w jedną całość. Pisze on: Zachodzi więc pytanie, jakim sposobem można, nie znając naukowo pomników jednej okolicy, wiązá́je w jedna grupę z pomnikami których charakter stylowy jest jasno określonym, a tak się stato z pośpiesznym utworzeniem wspólnego odcienia wiślano-battyckiego ${ }^{40}$. Architekturą dobrze zbadaną i o określonym stylu jest, według Euszczkiewicza, oczywiście architektura krakowska. Ceglany gotyk południowego pobrzeża Mo-

37 W. Łuszczkiewicz, Kilka stów o naszem budownictwie..., s. 53.

38 Konkurs na sporządzenie..., s. 263.

39 W. Łuszczkiewicz, Kilka stów o naszem budownictwie..., s. 53.

40 Tamże. 
rza Bałtyckiego pozostaje słabo rozpoznany. Co gorsza, jego geneza jest prawdopodobnie „germańska”. Opieranie współczesnej autorowi architektury na tych wzorach jest więc dla niego absurdalne - jak pisze, możemy [...] wskazać co jest wtaściwościa dodatnia, konstrukcyjna i estetyczna, wytacznie naszych zabytków $w^{41}$.

Pierwszy z argumentów mających dowodzić wyższości gotyku krakowskiego nad architekturą ceglaną „nizin niemieckich” oparty jest zatem na opozycji zbadanego, dobrze opisanego i operującego indywidualnymi rozwiązaniami konstrukcyjnymi oraz słabo zrozumianego, mechanicznie kopiowanego, nieposiadającego pewnej genezy.

Drugi argument odnosi się do kwestii użytego materiału. Łuszczkiewicz pisze: wspaniate pomniki budownictwa ceglanego pruskiego rzucaja się w oczy doskonatością techniki ceglanej i tym majestatem, które każde dzieto skończone, nie zmienione [...] na każdego znawcędziatać musi ${ }^{42}$. Można by zatem odnieść wrażenie, że autor docenia wartość artystyczną gotyku ceglanego. Chwilę później jednak dodaje: ale wobec prawdziwych pomników gotycyzmu kamiennych katedr i kościotów XIII i XIV wieku traca one na znaczeniu ${ }^{43}$. Oprócz systemu konstrukcyjnego jednym z najważniejszych wyróżników tzw. szkoły krakowskiej jest bowiem użycie cegły jedynie w celu wypełnienia ścian. Wszystkie najbardziej zajmujące badaczy części gotyckiej budowli, takie jak elementy konstrukcyjne, ościeża okien, detale, profilowania, portale itd. są już wykonane z kamienia. Zwróćmy uwagę, że w zacytowanym fragmencie to tylko kamienna architektura gotycka ma prawo nosić miano „prawdziwej”. Cegła jest tu synonimem ekonomicznego i artystycznego ubóstwa. Łuszczkiewicz odmawia wręcz budynkom wzniesionym w tym materiale miana „gotyckich”. Jak pisze, wtaściwy gotycyzm nie istnieje tam gdzie byt brak odpowiedniego kamienia ${ }^{44}$. $\mathrm{O}$ ile zatem w poprzednim przypadku mieliśmy do czynienia z opozycją dobrze poznanej architektury „polskiej” i słabo zrozumianej architektury „niemieckiej”, o tyle tutaj obserwujemy opozycję „prawdziwego” gotyku kamiennego i budownictwa, któremu właściwe nie przysługuje miano „gotyckiego", a jeśli już, to jest to gotyk co najmniej zubożały.

Dalej Łuszczkiewicz rozpoczyna wywód, w którym za pomocą kolejnych przykładów dowodzi, jak rozwiązania powszechnie stosowane w gotyku kamiennym zostały z uwagi na uboższy materiał zredukowane w gotyku ceglanym. Tym samym stara się udowodnić wyższość jednej architektury nad drugą.

W tym miejscu muszę podkreślić, iż nie jest moim celem krytyka tez Łuszczkiewicza z punktu widzenia współczesnej mediewistyki. Wydaje się oczywiste, iż w ciągu ponad stu lat badań nad architekturą gotycką w Polsce wiele z tez badacza zostało wielokrotnie zakwestionowanych. Wspomniany wywód jest jednak zastanawiający, gdyż, w mojej opinii, dyskusyjność tez nie wynika tu z kwestii metodologicznych czy z charakterystycznej dla badaczy XIX-wiecznych postawy. Rzecz w tym, że stwierdzenia Łuszczkiewicza są nie do obronienia nawet przy bardzo powierzchownym zestawieniu ich z podstawowym materiałem zabytkowym.

${ }_{41} \begin{aligned} & \text { Tamże. } \\ & { }_{4} \text { Tamże. } \\ & { }_{43} \text { Tamże. } \\ & { }_{4} \text { Tamże. }\end{aligned}$


Przykładowo autor pisze, iż z uwagi na zastosowanie cegły upada więc $w[\ldots]$ kosciotach system tak wspaniaty otoczenia prezbiterium niższemi nawami bocznymi i wieńcem kaplic ${ }^{45}$. Stwierdzenie to rozmija się jednak z kluczowymi dla krytykowanej architektury realizacjami. Cała seria kościołów meklemburskich posiada bowiem obejście $\mathrm{z}$ tzw. wieńcem kaplic zintegrowanych ${ }^{46}$. W tym kontekście dziełem powszechnie w XIX w. znanym, o którego istnieniu Łuszczkiewicz powinien wiedzieć, jest kościół Mariacki w Lubece ${ }^{47}$. Ponadto warto zwrócić uwagę, że wieloboczne obejście (choć bez kaplic) znajdujemy również w klasztorze w Oliwie. Z drugiej strony kościoły krakowskie tego rozwiązania nie powtarzają. Jedynie katedra wawelska posiada obejście, ale prostsze - prostokątne.

Przykładów tego rodzaju niespójności możemy w rozprawie Łuszczkiewicza znaleźć więcej. Pisze on na przykład: we wtaściwem budownictwie ceglanem nizin niemieckich, brak fantazyi opartej o zasady geometryczne $e^{48}$. Sąd ten wydaje się bardzo jednostronny, zważywszy na ogromne bogactwo figuracji sklepiennych będących jednym z podstawowych wyróżników krytykowanej architektury. Kolejnym dość wyrazistym przykładem jest też następujący fragment: $w$ polskich kościotach nie brak nigdy zaznaczenia rozdziatu czéści wnętrza kościelnego, wspaniata arkada, tak zwana tęcza, podczas gdy architekt niemiecki pomija ja najczęściej, przedtużając sklepienie nawy przedniej w prezbiterium, bez śladu rozdziatu (Toruń), lub też wiąze obie części w jedna catość nierozdzielna ${ }^{49}$. Kłopot jednak w tym, że spośród trzech zachowanych gotyckich kościołów toruńskich jedynie franciszkański odpowiada opisowi Łuszczkiewicza. Kościoły św. Jakuba oraz św. Janów ową arkadę wyraźnie oddzielającą prezbiterium od nawy posiadają.

Jeszcze jedna teza Łuszczkiewicza świadczy o niespójności jego krytyki z deklarowaną wielokrotnie w innych tekstach postawą badawczą. Pisze on: uktad bazylikowy, o waskiej nawie gtównej i prezbiteryum idacem w jej przedtużeniu, przy niższych i mniej jasnych nawach bocznych, posiada wyższość pod względem wrażen religijnych nad uktadem hallowym budownictwa pruskiego ${ }^{50}$. Po pierwsze, można by podać w wątpliwość samo już przypisanie budownictwu pruskiemu wyłącznie układu halowego, a w domyśle - architekturze krakowskiej „lepszego” układu bazylikowego. Bardziej zastanawiający jest tu jednak fragment odnoszący się do wzbudzania wrażeń religijnych. O ile w kontekście gotyku jest on w XIX w. rzeczywiście popularny, o tyle u Łuszczkiewicza pojawia się rzadko. Nie koresponduje on z racjonalną ewolucją rozwiązań konstrukcyjnych, która - w opinii autora - jest kluczem do zrozumienia architektury gotyckiej.

45 Tamże, s. 54.

46 W tym kontekście można wymienić m.in. klasztor cystersów w Doberanie, kościół Mariacki w Stralsundzie, kościół św. Mikołaja w Wismarze, kolegiatę NMP w Stargardzie Szczecińskim i wiele innych.

47 O lubeckim kościele Mariackim jako źródle inspiracji pisze m.in. architekt ostatecznie zrealizowanego projektu kościoła św. Floriana: J.P. Dziekoński, Kościót parafialny świętego..., s. 8.

48 W. Euszczkiewicz, Kilka stów o naszem budownictwie..., s. 54.

49 Tamże, s. 82.

50 Tamże. 
Przytoczone przykłady zdają się dobrze obrazować, że postawa badawcza Łuszczkiewicza względem gotyku ceglanego jest niekonsekwentna. Wielokrotnie podkreśla on konieczność skrupulatnych badań nad architekturą oraz istotność dobrego rozpoznania materiału zabytkowego. Tutaj jednak, może z uwagi na perswazyjny i polemiczny charakter tekstu, odchodzi całkowicie od tych założeń. Sformułowane przez niego tezy nie bronią się w zestawieniu z podstawowymi dla regionu budowlami. W tym kontekście symptomatyczny wydaje się fakt, iż w analizowanym artykule Łuszczkiewicz przywołuje jedynie trzy dość odległe przykłady: kościół NMP w Poznaniu, niedookreślone kościoły toruńskie i kościół św. Anny w Wilnie. Należy wobec tego postawić pytanie, czy badacz krytykuje architekturę, której sam dobrze nie zna. Czy może nieświadomie nagina rzeczywistość pod skonstruowaną przez siebie narrację? A może wreszcie jest to zabieg świadomy, którego celem jest wpłynięcie na architektów kościoła praskiego i skłonienie ich do oparcia się na wzorach architektury XIV-wiecznego Krakowa? Trudno tu o ostateczną odpowiedź. Dość jednoznaczne wydaje się jednak to, iż obie postawy (rozszerzająca i zawężająca) wiążą się z nadużyciami argumentacyjnymi i naginaniem materiału historycznego w celu osiągnięcia konkretnego celu.

\section{GRANICA RZECZYWISTA}

Nie ulega wątpliwości, iż styl wiślano-bałtycki był w polskim piśmiennictwie pojęciem silnie antagonizującym środowisko historyków i krytyków architektury. Zmagając się z zakresem przedmiotowym owego terminu, Martynowski i Łuszczkiewicz na różne sposoby starają się oddzielić to, co „swojskie”, od tego, co „obce”. Czy granica ta jest jednak tylko wyobrażona? Czy na czysto teoretycznym gruncie da się wytłumaczyć ogromną popularność analizowanego pojęcia i wiązanych z nim form?

W tym miejscu nie należy zapominać, że często dość złożone i hermetyczne rozważania XIX-wiecznych autorów powstają w odniesieniu do konkretnych budynków i ich materii. Bez zachowanych zabytków architektury średniowiecznej, jak również na nowo wznoszonych budynków, cała opisana powyżej dyskusja nie miałaby racji bytu. We współczesnej humanistyce coraz częściej zwraca się uwagę na rolę materialnych przedmiotów w aktywnym współtworzeniu otaczającej nas rzeczywistości społecznej. Problemem tym szerzej zajął się w swojej teorii aktora-sieci Brunon Latour. Jak twierdzi badacz, proste interakcje między ludźmi nie są w stanie wytworzyć więzi na tyle silnych, żeby zachowały one ważność w dłuższej perspektywie czasu ${ }^{51}$. Uwzględnienie aktywnej roli rzeczy w tworzeniu tego, co społeczne, pozwala na pełniejsze zrozumienie procesów stojących za m.in. interesującą mnie w niniejszym artykule kwestią tożsamości narodowej.

W moim przekonaniu powstające na przełomie XIX i XX w. na niespotykaną dotąd skalę neogotyckie kościoły parafialne stanowią, szczególnie w kontekście zaboru rosyjskiego, materialne narzędzie wyznaczania owej granicy wyobrażonej, o którą spierali

51 B. Latour, Splatając na nowo to, co spoteczne. Wprowadzenie do teorii aktora-sieci, przeł. A. Derra, wstęp K. Abriszewski, Kraków 2010, s. 89-122. 
się najważniejsi teoretycy epoki. By zobrazować skalę tego zjawiska, warto wspomnieć, iż w dorobku jednego tylko ówczesnego architekta - Józefa Piusa Dziekońskiego znajdziemy ponad 30 świątyń zrealizowanych głównie na prowincjii ${ }^{52}$. Nowo powstające kościoły, będąc relatywnie tanimi w wykonaniu i ekonomicznymi w utrzymaniu, podkreślały odrębność kulturową i wyznaniową ludności polskiej i konsolidowały wokół siebie lokalne społeczności. Strzeliste neogotyckie wieże, na podobieństwo słupów granicznych, wyznaczały obszar dominacji kultury łacińskiej, katolickiej i polskiej. Stanowiły symboliczne narzędzie zawłaszczania i znakowania krajobrazu. Warto przytoczyć tu za Jerzym Żywickim cytat z epoki, który dotyczy jednego z lubelskich kościołów: stojąc na wzniostym wzgórzu widocznym byt na szeroka okolicę i swa piękną wieżyca zdawat się mówić wjeżdżającemu: Patrzcie! Jam tu nad Bugiem jest znakiem polskości tej ziemi i symbolem kultury zachodniej ${ }^{53}$.

Oczywiście nie tylko na ziemiach polskich sięgano po gotyk w celu podkreślenia przynależności terytorium do określonej kultury, narodu czy wyznania. $Z$ uwagi na ograniczoną obszerność artykułu nie sposób w pełni omówić, jak polskie spory dotyczące architektonicznego dziedzictwa sytuują się wobec równolegle toczonych dyskusji w innych krajach europejskich. Niemniej warto podkreślić, iż zgłębienie tego problemu byłoby istotnym rozszerzeniem podjętych w tym artykule badań.

\section{WNIOSKI}

Poszukiwanie wyrazu dla tożsamości narodowej ma w polskiej teorii architektury długą historię. Spośród licznych koncepcji to nawiązujące do tradycji średniowiecznej pojęcie stylu wiślano-bałtyckiego stało się pierwszą próbą odpowiedzi na pytanie, czym architektura w Polsce się wyróżnia. Celem moich rozważań była analiza owego pojęcia. Próba jego zdefiniowania była polem do postawienia zasadniczych pytań dotyczących wyobrażonych granic polskości, jak również sposobów kulturowego zawłaszczania krajobrazu, podkreślania jego przynależności do kultury polskiej.

Bliższa analiza wybranych tekstów źródłowych ujawniła, iż w obu głównych nurtach poszukiwań cech dystynktywnych „polskiego gotyku” występują nadużycia argumentacyjne i naginanie materiału historycznego z zamiarem osiągnięcia pewnego konkretnego celu. Na ile jest to nieuświadomiona cecha sposobu uprawiania nauki w tamtym czasie, a na ile jest to celowe kreowanie rzeczywistości historycznej za pomocą narzędzi historii sztuki, pozostaje sprawą otwartą. Podkreślenia wymaga jednak kilka kwestii. Po pierwsze, że popularyzacja terminu „styl wiślano-bałtycki” jest procesem złożonym o trudno uchwytnej genezie, w którym splatają się problemy tożsamości gotyku w Polsce, rodzącej się mediewistyki oraz współczesnej autorom

52 Pełny katalog realizacji sakralnych Dziekońskiego znajdziemy w cytowanej już publikacji: A. Majdowski, Budownictwo kościelne...

53 Sprawozdanie o stanie parafii rzymsko-katolickiej w Dorohursku, Archiwum Parafialne w Dorohursku, 1933, za: J. Żywicki, Architektura neogotycka..., s. 77. 
architektury. Po drugie, że granica między tym, co swojskie, a tym, co obce, wyznaczana była przez autorów w bardzo różny sposób. W konsekwencji także argumentacje dowodzące takich, a nie innych granic różniły się miejscami zasadniczo. Po trzecie zaś, należy pamiętać, iż pod skrupulatną faktografią, rozpoznaniem zabytków i teoretycznie dążącą do obiektywizmu analizą kryją się często pewne arbitralne założenia oraz konkretny cel, który autorzy chcieliby osiągnąć. Jest nim m.in. dowiedzenie jak największej samodzielności i wartości polskiej sztuki gotyckiej. Ze współczesnej perspektywy wydaje się on nieadekwatny z uwagi na nieprzystawalność nowoczesnej koncepcji narodu do realiów średniowiecznych.

Nie oznacza to jednak, że architektura tworzona w powiązaniu z problemem kreowania narodowej tożsamości jest w jakikolwiek sposób mniej wartościowa bądź skompromitowana. Szukanie narodowej, religijnej, politycznej, lokalnej tożsamości w formach architektonicznych jest jedną z charakterystycznych cech umysłowości i kultury europejskiej tego okresu. W politycznie wrogich realiach zaboru rosyjskiego kościół św. Floriana, jak również liczne, często zapomniane przez historię sztuki neogotyckie kościoły parafialne stanowiły narzędzie materialnego konstruowania wyobrażonej granicy polskości. Tym samym wspomniane obiekty pozostają doskonałymi pomnikami swoich czasów.

\section{BIBLIOGRAFIA}

Art and Politics. The Proceedings of the Third Joint Conference of Polish and English Art Historians, red. F. Ames-Lewis, P. Paszkiewicz, Warszawa 1999.

Bałus W., Gotyk bez Boga? W kregu znaczeń symbolicznych architektury sakralnej XIX wieku, Toruń 2011.

Bałus W., Zjawisko historyzmu w architekturze wieku XIX. Próba opisu, „Dzieła i Interpretacje” $1995, \mathrm{nr} 3$.

Brykczyński A., Wjakim stylu najwtaściwiej u nas kościoty budować?, „Przegląd Katolicki” 1893, nr 46.

Budowa kościota parafialnego na przedmieściu Praga, „Przegląd Techniczny” 1888, t. 25, z. 5 .

Dziekoński J.P., Kościót parafialny świętego Floryana na Pradze pod Warszawa, "Architekt” 1900, nr 1.

Gadamer H.-G., Prawda i metoda. Zarys hermeneutyki filozoficznej, przeł. B. Baran, Warszawa 2004.

Konkurs na sporządzenie szkicu do projektu kościota dla parafii praskiej m. Warszawy, „Przegląd Techniczny" 1886, t. 23, z. 9.

Latour B., Splatajac na nowo to, co spoteczne: wprowadzenie do teorii aktora-sieci, przeł. A. Derra, wstęp K. Abriszewski, Kraków 2010.

Łuszczkiewicz W., Kilka stów o naszem budownictwie w epoce ostrotukowej i jego cechach charakterystycznych, „Przegląd Techniczny” 1887, z. 24, s. 3-6.

Łuszczkiewicz W., O znaczeniu $w$ dzisiejszych czasach budownictwa średniowiecznego. Kilka uwag z dziedziny sztuki, [w:] Ktosy i kwiaty, Kraków 1869. 
Łuszczkiewicz W., Pomniki architektury od XI do XVII wieku ze stanowiska historyi sztuki, t. 1, Kraków 1872.

Majdowski A., Budownictwo kościelne w twórczości projektowejJózefa Piusa Dziekońskiego (1844-1927), Warszawa 1995.

Majdowski A., Nurt narodowy $w$ architekturze sakralnej Królestwa Polskiego od drugiej potowy XIX wieku, „Nasza Przeszłość: studia z dziejów Kościoła i kultury katolickiej w Polsce” 1965, t. 64.

Majdowski A., O poglądach na styl wiślano-battycki w polskiej architekturze sakralnej XIX wieku, „Nasza Przeszłość: studia z dziejów Kościoła i kultury katolickiej w Polsce” 1992, t. 78.

Majdowski A., Studia z historii architektury sakralnej w Królestwie Polskim, Warszawa 1993.

Majdowski A., Z dziejów budowy kościota pw. świętych Michata i Floriana, [w:] Świątynie prawego brzegu. Kościót katolicki w dziejach prawobrzeżnej Warszawy, Warszawa 2009.

Martynowski F.K., Na przetomie sztuki polskiej, Warszawa 1882.

Martynowski F.K., O stylu wiślano-battyckim, „Wiek: Gazeta Polityczna, Literacka i Społeczna” 1887 , nr 51.

Matuszewski K., O architekturze u obcych i u nas uwagi ze stanowiska estetycznego, „Biblioteka Warszawska” 1881, t. 3.

Nacjonalizm w sztuce i historii sztuki 1789-1950, red. D. Konstantynow, R. Pasieczny, P. Paszkiewicz, Warszawa 1998.

Olszewski A., Przeglad koncepcji stylu narodowego w teorii architektury polskiej przetomu XIX i XX w., „Sztuka i Krytyka” 1956, t. 7, nr 3-4.

Sprawozdanie komisji konkursowej z osądzenia szkiców projektu budowy kościota dla parafii praskiej m. Warszawy, „Przegląd Techniczny” 1887, t. 24, z. 4.

Stefański K., Architektura XIX wieku na ziemiach polskich, Warszawa 2005.

Stefański K., Polska architektura sakralna w poszukiwaniu stylu narodowego, Łódź 2002.

Sztuka i historia. Materiaty sesji Stowarzyszenia Historyków Sztuki. Kraków, listopad 1988, red. M. Bielska-Łach, Warszawa 1992.

Tołłoczko Z., „Sen architekta” czyli o historii i historyzmie architektury XIX i XX wieku, Kraków 2015.

Żywicki J., Architektura neogotycka na Lubelszczyźnie, Lublin 1998.

Jan NOWICKI - doktorant na Wydziale Historycznym Uniwersytetu Warszawskiego. Zajmuje się recepcją średniowiecza w XIX i XX w., historią mediewistyki jako dyscypliny naukowej oraz architekturą gotycką i neogotycką. Absolwent Instytutu Historii Sztuki i Centrum Europejskiego Uniwersytetu Warszawskiego. 